\title{
PENGARUH KUALITAS PELAYANAN DAN PERSEPSI KONSUMEN TERHADAP LOYALITAS KONSUMEN DENGAN KEPUASAN KONSUMEN SEBAGAI VARIABEL INTERVENING PADA EKA PRIMA MOTOR PEMATANGSIANTAR
}

\author{
Oleh: \\ Nilam Pusvita Sari \\ S1 Manajemen \\ Darwin Lie, Marisi Butarbutar, Ady Inrawan
}

\begin{abstract}
Abstraksi
Adapun rumusan masalah penelitian ini adalah bagaimana pengaruh pelayanan dan persepsi konsumen terhadap loyalitas konsumen dengan kepuasan konsumen sebagai variable intervening pada Eka Prima Motor Pematangsiantar. Metode yang digunakan dalam penulisan ini adalah penelitian kepustakaan dan penelitian lapangan. Populasinya adalah seluruh konsumen Eka Prima Motor Pematangsiantar yang berjumlah 130 orang. Data yang digunakan adalah data kualitatif dan data kuantitatif, dan teknik pengumpulan data yang digunakan adalah metode kuesioner, metode wawancara dan metode dokumentasi. Kemudian teknik analisis data menggunakan metode deskriptif kualitatif dan metode deskriptif kuantitatif.

Hasil penelitian: 1. Kualitas pelayanan yang diberikan sudah baik, konsumen setuju dengan persepsi mereka, dan kepuasan konsumen sudah puas serta loyalitas konsumen sudah tinggi. 2. Kualitas pelayanan dan persepsi konsumen berpengaruh positif terhadap kepuasan konsumen yang dibuktikan dengan regresi $\hat{Y}_{Z}=8,042+0,345 X_{1}+0,506 X_{2}$. Kepuasan konsumen berpengaruh positif terhadap loyalitas konsumen yang dibuktikan dengan regresi $\hat{Y}=13,826+0,728 Z$. 3 . Kualitas pelayanan dan persepsi konsumen memiliki hubungan yang kuat dan positif dengan kepuasan konsumen yang dibuktikan dengan nilai $r=0,700$, dan nilai determinasi sebesar $48,9 \%$. Kepuasan konsumen memiliki hubungan yang kuat dan positif dengan loyalitas konsumen yang dibuktikan dengan nilai $r=0,687$, dan nilai determinasi sebesar $47,2 \%$. 4. Hasil uji hipotesis menyatakan $\mathrm{H} 0$ ditolak, artinya kualitas pelayanan dan persepsi konsumen berpengaruh positif dan signifikan terhadap loyalitas konsumen dengan kepuasan konsumen sebagai variabel intervening.
\end{abstract}

Kata kunci: Kualitas Pelayanan, Persepsi Konsumen, Kepuasan Konsumen, dan Loyalitas Konsumen

\section{Abstraction}

The formulation of this research problem is how the influence of service quality and consumer perception with consumer satisfaction as intervening variable on consumer loyalty at Eka Prima Motor Pematangsiantar. The method used in this paper is literature research and field research. The population is all consumer of Eka Prima Motor Pematangsiantar which amounted to 130 people. The data used are qualitative data and quantitative data, and data collection techniques used are questionnaire method, interview method and documentation method. Then the technique of data analysis using qualitative descriptive method and quantitative descriptive method.

Result of research: 1. The service quality is good, consumers agree with their perception, the cunsomer satisfaction is satisfied, and the consumer loyalty is high. 2. Service quality and consumer perception have a positive effect on cunsomer satisfaction as evidenced by regression $\hat{Y} Z=8,042+$ $0,345 X 1+0,506 X 2$. Consumer satisfaction has a positive effect on consumer loyalty as evidenced by regression $\hat{Y}=13,826+0,728 Z$. 3. Service quality and consumer perceptions have a moderately high and positive correlation with cunsomer satisfaction as evidenced by the value of $r=0,700$, and the value of determination of $48,9 \%$. Consumer satisfaction has a moderately high and positive correlation with consumer loyalty as evidenced by the value of $r=0,687$, and the value of determination of $47,2 \%$. 4. Hypothesis test results stated $\mathrm{HO}$ rejected, meaning service quality and consumer perception have positive and significant effect to consumer loyalty with consumer satisfaction as intervening variable.

Keywords: Service Quality, Consumer Perception, Consumer Satisfaction, and Consumer Loyalty

\section{A. PENDAHULUAN}

1. Latar Belakang Masalah

Eka Prima Motor Pematangsiantar merupakan salah satu usaha yang bergerak di bidang penjualan spare part dan jasa bengkel mobil. Perkembangan usaha bengkel mobil di kota Pematangsiantar sudah semakin pesat. Dengan perkembangan tersebut mengakibatkan berbagai macam persepsi konsumen terhadap bengkel mobil di kota Pematangsiantar. Hal ini mengakibatkan semakin ketatnya persaingan dalam bisnis bengkel mobil. Eka Prima Motor Pematangsiantar selalu berusaha memberikan pelayanan yang baik kepada konsumen 
sehingga dapat tercipta kepuasan konsumen dan menimbulkan konsumen yang loyal.

Eka Prima Motor Pematangsiantar dalam menarik dan mempertahankan konsumennya, selalu berusaha untuk menciptakan loyalitas melalui beberapa tahapan proses yang dapat diukur melalui beberapa dimensi yaitumelakukan pembelian secara terus menerus, membeli antar lini produk/jasa,mereferensikan kepada orang lain, dan menunjukkan kekebalan terhadap pesaing Berikut penulis melampirkan hasil wawancara mengenai persentase dimensi loyalitas konsumen pada Eka Prima Motor Pematangsiantar.

Tabel 1

Pengukuran Tingkat Loyalitas Konsumen

\begin{tabular}{|c|c|c|c|c|c|c|c|}
\hline No. & Indikator & ST & T & S & $R$ & SR & Total \\
\hline 1 & $\begin{array}{l}\text { Melakukgn pertelian } \\
\text { secaraterys reresis }\end{array}$ & 175 & 663 & 135 & 58 & 0 & $109 x$ \\
\hline 2 & $\begin{array}{l}\text { Memvei angr in } \\
\text { grcakijasa }\end{array}$ & 139 & 6685 & $17 \mathrm{~S}$ & $5 x$ & 0 & $190 x$ \\
\hline 3 & $\begin{array}{l}\text { Mereferensikan kepaja } \\
\text { acaglan }\end{array}$ & $16 \%$ & $68 \%$ & $15 \%$ & $5 x$ & 0 & $109 x$ \\
\hline 4 & $\begin{array}{l}\text { Menujussal keseded } \\
\text { tetarap pesarg }\end{array}$ & 165 & 668 & $15 \%$ & $5 \%$ & 0 & $109 \%$ \\
\hline & Rata-rata & $15 \%$ & 65 & $15 \%$ & $5 x$ & 0 & $100 \%$ \\
\hline
\end{tabular}

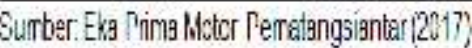

Pada tabel 1 di atas terlihat bahwa tingkat loyalitas konsumen pada Eka Prima Motor Pematangsiantar masih rendah. Hal ini dapat dilihat dari kategori sedang dengan hasil persentase sebesar $13 \%$ pada dimensi melakukan pembelian secara terus menerus. Dimana masih terdapat konsumen yang hanya sekali saja menggunakan jasa yang ditawarkan Eka Prima Motor Pematangsiantar. Pada dimensi membeli antar lini produk/jasa diperoleh hasil persentase terendah sebesar $17 \%$. Hal ini disebabkan masih adanya konsumen yang tidak menggunakan jasa lain yang ditawarkan Eka Prima Motor Pematangsiantar seperti jasa salon mobil dan audio mobil. Pada dimensi mereferensikan kepada orang lain diperoleh hasil persentase sebesar $15 \%$. Dimana masih adanya konsumen yang tidak mau mengajak teman atau keluarganya untuk menservis mobilnya ke Eka Prima Motor Pematangsiantar. Sedangkan pada dimensi menunjukkan kekebalan terhadap pesaing diperoleh hasil persentase sebesar $15 \%$. Dimana masih ada konsumen yang tidak konsisten menggunakan jasa bengkel di Eka Prima Motor Pematangsiantar.

Salah satu faktor yang menyebabkan konsumen loyal adalah hasil dari kepuasan konsumen. Kepuasan konsumen memiliki beberapa dimensi yaitu kualitas produk, harga produk, kenyamanan prosedur, dan dukungan konsumen. Berikut hasil pra survey pada 30 orang konsumen mengenai persentase dimensi kepuasan konsumen pada Eka Prima Motor Pematangsiantar:

Tabel 2

Pengukuran Tingkat Kepuasan Konsumen

\begin{tabular}{|c|c|c|c|c|c|c|c|}
\hline iv. & Indikator & $S P$ & $P$ & $C P$ & $\mathbb{T P}$ & STP & 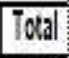 \\
\hline 1 & Kuarizs Prouka & 103 & 660 & $25 \%$ & 0 & J & \\
\hline$?$ & HaygaPock & $5 \%$ & $6 \mathrm{OS}^{\circ}$ & 358 & 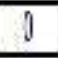 & j & \\
\hline 3 & Kenyanaาan Frosedu & $15 \%$ & 6560 & 309 & 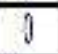 & j & \\
\hline 4 & Dikungan Korsumen & $19 x$ & $6 \mathrm{SS}$ & $30 \%$ & 0 & 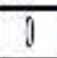 & 10. \\
\hline & Dang & Ph & Whi & 305 & $\pi$ & 0 & \\
\hline
\end{tabular}

Surber.pra sureey dencan 30 crang konsumen, uuri 2017

Dari tabel 2 di atas dapat dilihat bahwa kepuasan konsumen pada Eka Prima Motor Pematangsiantar masih belum optimal. Hal ini dapat dilihat dari kategori cukup puas diperoleh hasil persentase untuk dimensi kualitas produk atau jasa sebesar 25\%. Hal ini disebabkan adanya beberapa produk yang memiliki mutu yang kurang baik. Pada dimensi harga produk diperoleh hasil persentase terendah sebesar $35 \%$, hal ini disebabkan adanya konsumen yang merasa harga yang ditawarkan masih terlalu mahal. Pada dimensi kenyamanan prosedur diperoleh hasil persentase sebesar $30 \%$. Dimana adanya konsumen yang merasa kurang nyaman ketika melakukan perbaikan mobil, seperti kurangnya fasilitas bagi konsumen yang sedang menunggu. Sedangkan pada dimensi dukungan konsumen diperoleh hasil persentase sebesar 30\%. Dimana masih ada karyawan yang mengabaikan keluhan dari konsumen.

Kualitas pelayanan memiliki kaitan yang erat dengan kepuasan konsumen dalam menciptakan konsumen yang loyal. Kualitas pelayanan yang baik terdapat lima dimensi didalamnya yaitu bukti langsung (tangibles), Kehandalan (reliability), daya tanggap (responsiveness), jaminan (assurance), dan empati (empathy). Fenomena kualitas pelayanan yang diberikan Eka Prima Motor Pematangsiantar masih kurang maksimal. Hal ini disebabkan kurang lengkapnya seragam karyawan, adanya karyawan yang belum sepenuhnya memahami tentang kerusakankerusakan yang terjadi pada mesin mobil, dan kurangnya fasilitas bagi konsumen yang sedang menunggu.

Selanjutnya, kepuasan konsumen dapat ditentukan langsung oleh persepsi konsumen terhadap produk dan jasa yang ditawarkan. Persepsi konsumen memiliki sifat yang tidak tetap atau dapat berubah-ubah mengikuti perkembangan teknologi, sosial budaya, dan ekonomi. Beberapa dimensi persepsi konsumen meliputi perhatian selektif, distorsi selektif, dan retensi selektif. Dari pengamatan sementara penulis di Eka Prima Motor Pematangsiantar, pada dimensi atensi selektif, konsumen masih kurang memperhatikan informasi yang diberikan 
oleh pihak Eka Prima Motor Pematangsiantar. Pada dimensi distorsi selektif keyakinan konsumen terhadap Eka Prima Motor Pematangsiantar belum maksimal karena tidak semua konsumen meyakini bahwa Eka Prima Motor Pematangsiantar adalah bengkel yang terbaik dibandingkan bengkel lain. Pada dimensi ingatan selektif, konsumen selalu mengingat hal-hal baik yang mereka dapatkan dari Eka Prima Motor Pematangsiantar. Oleh karena itu, Eka Prima Motor Pematangsiantar selalu berupaya menciptakan persepsi yang positif dari konsumen.

\section{Rumusan Masalah}

a. Bagaimana gambaran kualitas pelayanan, persepsi konsumen, kepuasan konsumen, dan loyalitas konsumen pada Eka Prima Motor Pematangsiantar.

b. Bagaimana pengaruh kualitas pelayanan dan persepsi konsumen terhadap kepuasan konsumen pada Eka Prima Motor Pematangsiantar secara simultan.

c. Bagaimana pengaruh kualitas pelayanan dan persepsi konsumen terhadap kepuasan konsumen pada Eka Prima Motor Pematangsiantar secara parsial.

d. Bagaimana pengaruh kepuasan konsumen terhadap loyalitas konsumen pada Eka Prima Motor Pematangsiantar.

\section{Tujuan Penelitian}

a. Untuk mengetahui gambaran kualitas pelayanan, persepsi konsumen, kepuasan konsumen, dan loyalitas konsumen pada Eka Prima Motor Pematangsiantar.

b. Untuk mengetahui pengaruh kualitas pelayanan dan persepsi konsumen terhadap kepuasan konsumen pada Eka Prima Motor Pematangsiantar secara simultan.

c. Untuk mengetahui pengaruh kualitas pelayanan dan persepsi konsumen terhadap kepuasan konsumen pada Eka Prima Motor Pematangsiantar secara parsial.

d. Untuk mengetahui pengaruh kepuasan konsumen terhadap loyalitas konsumen pada Eka Prima Motor Pematangsiantar.

\section{Metode Penelitian}

Objek penelitian adalah Eka Prima Motor Pematangsiantar yang terletak di Jalan Jend. A. Yani No. 126, Kelurahan Merdeka, Kecamatan Siantar Timur, Telp. (0622) 7551597, Kode Pos 21111, Kota Pematangsiantar. Populasi adalah rata-rata jumlah konsumen tetap yang datang setiap bulan selama tahun 2016 yang berjumlah 193 orang. Setelah dihitung dengan rumus Slovin, maka sampel adalah 130 orang.

Desain penelitian adalah Penelitian Kepustakaan (Library Research) dan Penelitian Lapangan (Field Research). Teknik pengumpulan data berupa Kuesioner, Wawancara, dan Dokumentasi. Jenis data yang adalah jenis data kualitatif dan data kuantitatif. Hasil data yang diperoleh dari lapangan akan dianalisis secara deskriptif baik bersifat kualitatif dan kuantitatif.

\section{B. LANDASAN TEORI}

\section{Kualitas Pelayanan}

Menurut Tjiptono dan Walkin (2007:121), mengemukakan bahwa kualitas pelayanan sebagai ukuran seberapa bagus tingkat layanan yang diberikan mampu sesuai dengan ekspektasi pelanggan. Kualitas pelayanan bisa diwujudkan melalui pemenuhan dan keinginan pelanggan serta ketepatan penyampaiannya untuk mengimbangi harapan pelanggan. Sedangkan menurut Lovelock dan Laurence (2005:96), mengatakan kualitas jasa didasarkan pada evaluasi kognitif jangka panjang terhadap penyerahan jasa perusahaan. Jadi kualitas jasa adalah tingkat keunggulan yang diinginkan dan pengendalian atas tingkat keunggulan tersebut untuk memenuhi keinginan pelanggan. Berdasarkan uraian di atas dapat disimpulkan bahwa kualitas pelayanan adalah tingkat kemampuan perusahaan untuk pemenuhan kebutuhan dan keinginan konsumen serta ketepatan penyampaiannya dalam mengimbangi harapan konsumen. Menurut Parasuraman, Zeithaml, dan Bery dalam Tjiptono dan Gregorius (2011:196) ada lima indikator dimensi kualitas pelayanan yaitu bukti langsung (tangible), kehandalan (reliability), daya tanggap (responsiveness), jaminan (assurance), dan empati (empathy). Menurut Sunarto (2003:244), ada tujuh dimensi dasar dari kualitas yaitu kinerja, interaksi pegawai, keandalan, daya tahan, ketepatan waktu dan kenyamanan, estetika, dan kesadaran merek. Sedangkan menurut Hutt dan Speh dalam Nasution (2004:47), kualitas pelayanan terdiri dari tiga dimensi yaitu technical quality, functional quality, dan corporate image. Berdasarkan uraian di atas dapat disimpulkan beberapa dimensi yang kredibel yaitu dengan memenuhi syarat agar sebuah pelayanan memungkinkan untuk menimbulkan kepuasan pelanggan dalam memenuhi kebutuhan konsumen, dimensi kualitas pelayanan juga memberikan nilai tambah dalam hal mendorong keinginan pelanggan untuk membeli barang atau menggunakan jasa kita.

\section{Persepsi Konsumen}

Menurut Schiffman dan Leslie (2007:137), persepsi didefinisikan sebagai proses yang dilakukan individu untuk memilih, mengatur, dan menafsirkan stimuli ke dalam gambar yang berarti masuk akal mengenai dunia. Menurut Kotler dan Gary (2004:218), persepsi adalah proses menyeleksi, mengatur, dan menginterpretasikan informasi guna membentuk gambaran yang berarti tentang dunia. Sedangkan menurut Setiadi (2008:159), 
persepsi merupakan suatu proses yang timbul akibat adanya sensasi, dimana sensasi adalah aktivitas merasakan atau penyebab keadaan emosi yang menggembirakan. Berdasarkan uraian di atas penulis menyimpulkan bahwa persepsi konsumen merupakan proses mengidentifikasi, mengatur, menginterpretasikan informasi guna melihat gambaran tentang suatu hal yang dilihat atau dirasakan. Menurut Kotler dan Kevin (2007:228), ada tiga proses persepsi yaitu perhatian selektif, distorsi selektif, dan ingatan selektif. Menurut Kotler dan Gary (2004:219), ada tiga proses perseptual yang dapat membentuk persepsi yaitu perhatian selektif, distorsi selektif, dan retensi selektif. Sedangkan menurut Setiadi (2008:11), beberapa sikap yang dapat mempengaruhi persepsi yaitu sikap, motivasi, minat, pengalaman masa lalu, harapan, sasaran, dan situasi. Berdasarkan uraian di atas penulis mengambil kesimpulan bahwa indikator persepsi setiap konsumen berbeda ditinjau dari bagaimana konsumen tersebut memberikan perhatian terhadap objek, melakukan distorsi kepada objek tersebut dan mengalami retensi. Hal ini dapat berarti bahwa pemasar harus bekerja keras agar pesan yang disampaikan dapat diterima oleh konsumen.

\section{Kepuasan Konsumen}

Menurut Lupiyoadi dan Hamdani (2008:192), kepuasan adalah tingkat perasaan dimana seseorang menyatakan hasil perbandingan atas kinerja produk (jasa) yang diterima dan diharapkan. Menurut Tjiptono (2007:349), kepuasan konsumen adalah situasi kognitif pembeli berkenaan dengan kesepadanan atau ketidaksepadanan antara hasil yang didapatkan dibandingkan dengan pengorbanan yang dilakukan. Dengan kata lain, kepuasan pelanggan merupakan penilaian evaluatif purnabeli yang dihasilkan dari seleksi pembelian spesifik. Sedangkan menurut Kotler dan Kevin (2009:177), kepuasan konsumen adalah perasaan senang atau kecewa seseorang yang muncul setelah membandingkan kinerja (hasil) produk yang dipikirkan terhadap kinerja (hasil) yang diharapkan. Jika kinerja berada dibawah harapan maka konsumen akan puas, jika kinerja memenuhi harapan maka konsumen akan puas, dan jika kinerja melebihi harapan makakonsumen akan sangat puas. Berdasarkan uraian diatas dapat disimpulkan bahwa kepuasan konsumen merupakan perasaan yang ditunjukkan oleh konsumen dengan membandingkan kinerja atau hasil yangdiharapkan. Apabila kinerja lebih rendah dari harapan konsumen maka konsumen akan merasa kecewa. Sebaliknya apabila kinerja atau hasil sesuai atau lebih dari harapan maka konsumen akan merasa puas. Menurut Lupiyoadi dan Hamdani (2006:192), ada empat faktor yang dapat mempengaruhi kepuasan konsumen yaitu kualitas produk atau jasa, harga produk, kenyamanan prosedur, dan dukungan konsumen. Menurut Juwandi (2004:37), faktor-faktor pendorong kepuasan konsumen terdiri dari lima bagian yaitu kualitas produk, harga, kualitas jasa, emotional factor, dan kemudahan. Sedangkan menurut Irawan (2003:332), ada empat atribut utama kepuasan pelanggan yaitu kualitas produk, harga, kemudahan, dan faktor emosional. Berdasarkan uraian di atas dapat disimpulkan bahwa beberapa dimensi kepuasan konsumen adalah kualitas produk yang baik, harga yang terjangkau oleh konsumen, memberikan pelayanan sesuai standar perusahaan, mengurangi kesalahan, serta memberikan sikap yang ramah tamah kepada pelanggan.

\section{Loyalitas Konsumen}

Menurut Kotler dan Kevin (2009:8), loyalitas atau kesetiaan didefinisikan sebagai komitmen yang dipegang kuat untuk membeli atau berlangganan lagi produk atau jasa tertentu di masa depan meskipun ada pengaruh situasi dan usaha pemasaran yang berpotensi menyebabkan perubahan perilaku. Menurut Tjiptono (2000:110), loyalitas konsumen adalah komitmen pelanggan terhadap suatu merek, toko, atau pemasok berdasarkan sifat yang sangat positif dalam pembelian jangka panjang.Sedangkan menurut Griffin (2003:31), loyalitas merupakan perilaku membeli berulang secara teratur, membeli antar lini produk dan jasa, mereferensikan kepada orang lain, menunjukkan kekebalan terhadap tarikan dari pesaing. Pelanggan yang dianggap loyal akan berlangganan atau melakukan pembelian ulang selama jangka waktu tertentu. Berdasarkan uraian di atas dapat disimpulkan bahwa loyalitas pelanggan merupakan bukti bahwa konsumen tersebut setia kepada perusahaan dan suatu keinginan konsumen untuk melakukan pembelian yang berulang-ulang. Menurut Griffin (2003:31), ada beberapa karakteristik loyalitas berdasarkan perilaku konsumen yakni melakukan pembelian secara terus menerus, membeli antar lini produk/jasa, mereferensikan kepada orang lain, dan menunjukkan kekebalan terhadap pesaing. Menurut Tjiptono (2005:85), mengemukakan karakteristik loyalitas konsumen, yaitu pembelian ulang, kebiasaan mengkonsumsi produk, selalu menyukai produk tersebut, yakin bahwa produk tersebut adalah produk terbaik, dan merekomendasikan produk kepada orang lain. Dari defenisi di atas dapat disimpulkan bahwa indikator loyalitas merupakan pembelian yang dilakukan secara berulang-ulang terhadap produk sehingga terjadi hubungan yang saling menguntungkan.

\section{PEMBAHASAN}

1. Analisa 


\section{a. Deskriptif Kualitatif}

Analisis deskriptif dimaksudkan untuk mendapatkan gambaran atau deskrips mengenai tanggapan dari konsumen mengenai pengaruh kualitas pelayanan dan persepsi konsumen terhadap loyalitas konsumen dengan kepuasan konsumen sebagai variabel intervening pada Eka Prima Motor Pematangsiantar. Setelah pengujian data, maka langkah selanjutnya peneliti melakukan pengkajian analisis kualitatif sebagai gambaran fenomena dari variabel penelitian pada saat sekarang ini. Adapun penetapan kriteria nila rata-rata jawaban dari responden tersebut dimasukkan ke dalam kelas-kelas interval dimana penentuan intervalnya memakai rumus sebagai berikut:

Interval Kelas $=$ Nilai Tertinggi - Nilai Terendah

$$
\begin{aligned}
& =\frac{5-1}{5} \\
& =\frac{4}{5} \\
& =0,8
\end{aligned}
$$

Dari rumus diatas dapat diperoleh interval kelas 0,8 sehingga berlaku ketentuan kategori dengan hasil berikut:

Tabel 3

\begin{tabular}{|c|c|c|c|c|}
\hline \multicolumn{5}{|c|}{ Responden } \\
\hline \multirow[b]{2}{*}{ Nilai Interval } & \multicolumn{4}{|c|}{ Kategori } \\
\hline & $\begin{array}{c}\text { Kualitas } \\
\text { Peloyanan }\end{array}$ & $\begin{array}{l}\text { Persepsi } \\
\text { Konsumen }\end{array}$ & $\begin{array}{l}\text { Kepuasan } \\
\text { Konsumen }\end{array}$ & $\begin{array}{l}\text { Loyaliths } \\
\text { Konsumen }\end{array}$ \\
\hline $1,00-1,80$ & $\begin{array}{l}\text { Sandad } \\
\text { Ticak Baik }\end{array}$ & $\begin{array}{c}\text { Sercost } \\
\text { Ticak Setuu }\end{array}$ & $\begin{array}{c}\text { Saryat: } \\
\text { Trak Fuas }\end{array}$ & $\begin{array}{l}\text { Sanjal } \\
\text { Rercah }\end{array}$ \\
\hline $1,81-2,0$ & Tilick Baik & Tick Stum & Tuds Fuds & Retldil \\
\hline $2,01-3,40$ & Cukup Bak & $\begin{array}{l}\text { Cukip } \\
\text { Seflijil. }\end{array}$ & GukMP Puas & Sedang \\
\hline $3,41-4,2$ & Bak & Sefili.ı & Pilas & Tnjyi \\
\hline $4,21-5,00$ & SangatBak & $\begin{array}{l}\text { Sargat } \\
\text { Seviuj] }\end{array}$ & Sancal Plas & $\begin{array}{l}\text { Sanyal. } \\
\text { | nyj| }\end{array}$ \\
\hline
\end{tabular}

Nilai Interval dan Kategori Jawaban Responden

Sumber : hasil pengolahan data

\section{1) Gambaran Kualitas Pelayanan pada Eka \\ Prima Motor Pematangsiantar \\ Pada dimensi bukti langsung (tangible)} berupa karyawan tidak menggunakan seragam kerja dan penggunaan peralatan yang cukup canggih dan berkualitas. Pada dimensi kehandalan (reliability) berupa karyawan berusaha mendengar atau memperhatikan setiap keluhan konsumen dan memberikan solusi yang terbaik. Pada dimensi daya tanggap (responsiveness) berupa kesediaan karyawan dalam membantu konsumen dan memberikan pelayanan yang tepat waktu.

Pada dimensi jaminan (assurance) berupa pengetahuan dan kesopanan karyawan untuk menciptakan keyakinan dan kepercayaan dari konsumen. Dalam meyakinkan konsumen, karyawan berusaha melayani dengan sopan dan senyum yang ramah kepada konsumen sehingga konsumen merasa yakin dan dihargai. Pada dimensi empati (empathy) berupa pemberian perhatian kepada konsumen dengan menyediakan kursi dan memberikan minuman ringan untuk konsumen yang sedang menunggu.

Secara keseluruhan dapat dilihat bahwa rata-rata kualitas pelayanan yang diberikan kepada konsumen berada pada nilai rata-rata 3,74 dengan kriteria jawaban baik. Kemudian nilai rata-rata tertinggi sebesar 4,05 dengan kriteria jawaban baik pada dimensi jaminan (assurance) dengan indikator kesopanan karyawan dalam melayani konsumen. Sedangkan nilai rata-rata terendah sebesar 2,57 dengan kriteria jawaban tidak baik pada dimensi bukti langsung dengan indikator kelengkapan seragam karyawan pada Eka Prima Motor Pematangsiantar.

\section{2) Gambaran Persepsi Konsumen pada Eka Prima Motor Pematangsiantar}

Pada dimensi perhatian selektif, konsumen selalu memperhatikan informasi yang diterima dari Eka Prima Motor Pematangsiantar. Pada dimensi distorsi selektif yaitu kemauan konsumen untuk menafsirkan informasi yang diterima mengenai Eka Prima Motor Pematangsiantar dan meyakini bahwa Eka Prima Motor Pematangsiantar merupakan bengkel yang terbaik dibandingkan bengkel lain. Pada dimensi ingatan selektif yaitu kemauan konsumen untuk selalu mengingat hal-hal baik yang diterima dari Eka Prima Motor Pematangsiantar. Toko Eka Prima Motor Pematangsiantar selalu berupaya menciptakan persepsi yang positif dari konsumen dengan memberikan pelayanan dan menawarkan produk yang berkualitas.

Secara keseluruhan dapat dilihat bahwa rata-rata persepsi konsumen berada pada nilai rata-rata 3,63 dengan kriteria jawaban setuju. Kemudian nilai rata-rata tertinggi sebesar 4,03 dengan kriteria jawaban setuju pada dimensi perhatian selektif dengan indikator memperhatikan informasi yang disampaikan karyawan. Sedangkan nilai rata-rata terendah sebesar 2,92 dengan kriteria jawaban cukup setuju pada dimensi ingatan selektif dengan indikator memilih Eka Prima Motor Pematangsiantar tanpa memperhatikan bengkel lain.

\section{3) Gambaran Kepuasan Konsumen pada \\ Eka Prima Motor Pematangsiantar}

Dalam menilai kepuasan konsumen pada Eka Prima Motor Pematangsiantar digunakan beberapa faktor diantaranya adalah kualitas produk atau jasa yaitu pihak Eka Prima Motor Pematangsiantar menyediakan produk-produk spare part dan memberikan jasa perbaikan mobil yang berkualitas. Harga produk yaitu 
memberikan penawaran harga yang sesuai dengan kualitas produk dan jasa, namun dalam hal ini konsumen merasa harga yang ditawarkan cukup mahal. Kenyamanan prosedur yaitu memberikan kemudahan dan efisiensi saat melakukan perbaikan sesuai dengan prosedur yang ditetapkan oleh Eka Prima Motor Pematangsiantar. Dukungan konsumen yaitu meyakinkan konsumen bahwa pelayanan yang diterima dilakukan secara maksimal dan dapat memberikan kepuasan bagi konsumen.

Secara keseluruhan dapat dilihat bahwa rata-rata loyalitas konsumen Eka Prima Motor berada pada nilai rata-rata 3,82 dengan kriteria jawaban tinggi. Kemudian nilai rata-rata tertinggi sebesar 4,08 dengan kriteria jawaban tinggi pada dimensi mereferensikan kepada orang lain dengan indikator mengajak teman untuk datang ke Eka Prima Motor. Sedangkan nilai rata-rata terendah sebesar 2,98 dengan kriteria jawaban sedang pada dimensi membeli antar lini produk dan jasa dengan indikator menggunakan produk atau jasa lain yang ditawarkan oleh Eka Prima Motor Pematangsiantar.

\section{4) Gambaran Loyalitas Konsumen pada Eka Prima Motor Pematangsiantar}

Loyalitas konsumen merupakan hal yang penting dan perlu diperhatikan oleh perusahaan. Menciptakan konsumen yang loyal bukan hal yang mudah untuk dilakukan. Selain membutuhkan waktu yang lama, juga membutuhkan biaya yang tidak sedikit. Konsumen yang loyal merupakan harapan yang ingin dicapai oleh perusahaan.

Dalam menciptakan loyalitas konsumen pada Eka Prima Motor Pematangsiantar dilakukan beberapa tahapan proses yang dapat diukur melalui beberapa dimensi yaitu melakukan pembelian secara terus menerus, membeli antar lini produk atau jasa, mereferensikan kepada orang lain, dan menunjukkan kekebalan terhadap pesaing.

Dalam hal melakukan pembelian secara terus menerus dapat dilihat dari kemauan konsumen untuk melakukan pembelian lebih dari dua kali dan berulang. Dalam hal membeli antar lini produk dan jasa dapat dilihat dari keinginan konsumen untuk membeli produk dan jasa lain yang ditawarkan Eka Prima Motor Pematangsiantar, namun hanya sedikit konsumen yang mau menggunakan produk atau jasa lain yang ditawarkan seperti salon mobil dan audio mobil.

Proses mereferensikan kepada orang lain dapat dilihat dari konsumen yang dengan sukarela merekomendasikan Eka Prima Motor Pematangsiantar kepada teman dan keluarganya. Dalam hal menunjukkan kekebalan terhadap pesaing dapat dilihat dari konsumen yang tidak mudah terpengaruh oleh persaingan usaha sejenisnya.

Secara keseluruhan dapat dilihat bahwa rata-rata loyalitas konsumen Eka Prima Motor berada pada nilai rata-rata 3,82 dengan kriteria jawaban tinggi. Kemudian nilai rata-rata tertinggi sebesar 4,08 dengan kriteria jawaban tinggi pada dimensi mereferensikan kepada orang lain dengan indikator mengajak teman untuk datang ke Eka Prima Motor. Sedangkan nilai rata-rata terendah sebesar 2,98 dengan kriteria jawaban sedang pada dimensi membeli antar lini produk dan jasa dengan indikator menggunakan produk atau jasa lain yang ditawarkan oleh Eka Prima Motor Pematangsiantar.

\section{b. Deskriptif Kuantitatif}

1) Regresi Linear

a) Pengaruh Kualitas Pelayanan dan Persepsi Konsumen terhadap Kepuasan Konsumen

Untuk menganalisa pengaruh kualitas pelayanan $\left(X_{1}\right)$ dan persepsi konsumen $\left(X_{2}\right)$ terhadap kepuasan konsumen (Z) pada Eka Prima Motor Pematangsiantar digunakan analisis regresi berganda. Dengan menggunakan bantuan program SPSS versi 21 , didapatkan hasil regresi sebagai berikut:

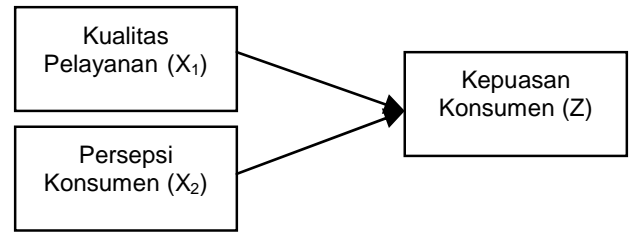

Tabel 4

Hasil Regresi Linier Berganda Coefficients $^{a}$

\begin{tabular}{|c|c|c|c|}
\hline \multirow[t]{2}{*}{ Nodel } & \multicolumn{2}{|c|}{$\begin{array}{l}\text { Unstandaroüzed } \\
\text { Coefficients }\end{array}$} & $\begin{array}{l}\text { Standardized } \\
\text { Coefficients }\end{array}$ \\
\hline & $B$ & Sol. Error & Beta \\
\hline Consends & 8,042 & 3285 & \\
\hline 1 Kualtas Pelayanan &, 345 & 0108 & 425 \\
\hline Persepsi Konsumen &, 506 & 125 & 341 \\
\hline
\end{tabular}

a. Dependent Variabel: Kepuasan Konsumen Sumber: hasil pengolahan data dengan SPSS versi 21

Berdasarkan hasil pengolahan data pada tabel 4 di atas diperoleh model persamaan $\hat{Y}_{Z}$ $=8,042+0,345 X_{1}+0,506 X_{2}$, artinya terdapat pengaruh yang positif antara kualitas pelayanan dan persepsi konsumen terhadap kepuasan konsumen pada Eka Prima Motor Pematangsiantar.

\section{b) Pengaruh Kualitas Pelayanan terhadap Kepuasan Konsumen}

Untuk menganalisa pengaruh kualitas pelayanan $\left(X_{1}\right)$ terhadap kepuasan konsumen (Z) pada Eka Prima Motor Pematangsiantar, digunakan analisis regresi linier sederhana. 
Dengan menggunakan bantuan program SPSS versi 21, didapatkan hasil regresi sebagai berikut:

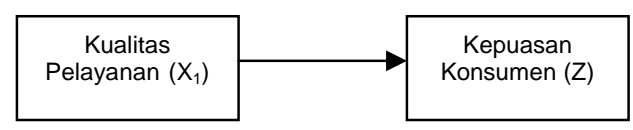

Tabel 5

Hasil Regresi Linier Sederhana Coefficients $^{\text {a }}$

\begin{tabular}{|c|c|c|c|}
\hline \multirow[t]{2}{*}{ Model } & \multicolumn{2}{|c|}{$\begin{array}{c}\text { Unswandardized } \\
\text { Coetincients }\end{array}$} & $\begin{array}{l}\text { Srandardized } \\
\text { Coefficients }\end{array}$ \\
\hline & $\bar{B}$ & Soro. Enror & Beta \\
\hline (Conslondi) & 14,296 & 3069 & \\
\hline Kualtias Pallayanan & 529 & 154 & 609 \\
\hline
\end{tabular}

a. Dependent Variable: Kepuasan Konsumen Sumber: hasil pengolahan data dengan SPSS versi 21 (2017)

Berdasarkan hasil pengolahan data pada tabel 5 di atas, diperoleh model persamaan $\hat{Y}_{Z}=$ $14,296+0,529 X_{1}$, artinya terdapat pengaruh yang positif antara kualitas pelayanan terhadap kepuasan konsumen pada Eka Prima Motor Pematangsiantar.

\section{c) Pengaruh Persepsi Konsumen terhadap Kepuasan Konsumen}

Untuk menganalisa pengaruh persepsi konsumen $\left(X_{2}\right)$ terhadap kepuasan konsumen (Z), digunakan analisis regresi linier sederhana. Dengan menggunakan bantuan program SPSS versi 21, didapatkan hasil regresi sebagai berikut:

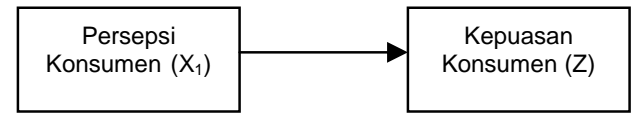

Tabel 6

Hasil Regresi Linier Sederhana Coefficients $^{a}$

\begin{tabular}{|c|c|c|c|}
\hline \multirow[t]{2}{*}{ Model } & \multicolumn{2}{|c|}{$\begin{array}{c}\text { Unstandardized } \\
\text { Coesficicinsts }\end{array}$} & $\begin{array}{l}\text { Srandarofized } \\
\text { Coefficicins }\end{array}$ \\
\hline & $B$ & Stod Error & Beter \\
\hline (Consibentit) & 13,774 & 3,366 & \\
\hline Pessensiknnsumen & 924 & 103 & 323 \\
\hline
\end{tabular}

b. Dependent Variable: Kepuasan Konsumen Sumber: hasil pengolahan data dengan SPSS versi 21 (2017)

Berdasarkan hasil pengolahan data pada tabel 6 di atas, diperoleh model persamaan $\hat{Y}_{Z}=$ $13,774+0,924 \mathrm{X}_{2}$, artinya terdapat pengaruh yang positif antara persepsi konsumen terhadap kepuasan konsumen pada Eka Prima Motor Pematangsiantar.

\section{d) Pengaruh Kepuasan Konsumen terhadap Loyalitas Konsumen}

Untuk menganalisa pengaruh kepuasan konsumen $(\mathrm{Z})$ terhadap loyalitas konsumen $(\mathrm{Y})$, digunakan analisis regresi linier sederhana. Dengan menggunakan bantuan program SPSS versi 21, didapatkan hasil regresi sebagai berikut:

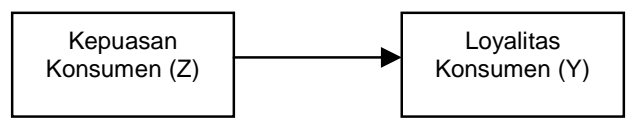

Tabel 7

Hasil Regresi Linier Sederhana Coefficients $^{a}$

\begin{tabular}{|c|c|c|c|}
\hline \multirow[t]{2}{*}{ Nodel } & \multicolumn{2}{|c|}{$\begin{array}{l}\text { Unstandardized } \\
\text { Coefficients }\end{array}$} & $\begin{array}{l}\text { Standarolized } \\
\text { Coefficienns }\end{array}$ \\
\hline & $B$ & Sto. Error & Beta \\
\hline - Constan" & 13,826 & 3,007 & \\
\hline Kepuasan Konsimen &, 728 & .660 & $68 ?$ \\
\hline
\end{tabular}

c. Dependent Variable: Loyalitas Konsumen Sumber: hasil pengolahan data dengan SPSS versi 21 (2017)

Berdasarkan hasil pengolahan data pada tabel 7 di atas, diperoleh model persamaan $\hat{Y}=$ $13,826+0,728 Z$, artinya terdapat pengaruh yang positif antara kepuasan konsumen terhadap loyalitas konsumen pada Eka Prima Motor Pematangsiantar.

2) Korelasi dan Koefisien Determinasi

a) Hubungan antara Kualitas Pelayanan dan Persepsi Konsumen dengan Kepuasan Konsumen

Hasil korelasi dan koefisien determinasi dapat dilihat pada tabel berikut:

Tabel 8

Hasil Korelasi dan Koefisien Determinasi Model Summary

\begin{tabular}{|c|c|c|c|c|}
\hline Model & $R$ & R Square & Adjusied R Squere & $\begin{array}{l}\text { Sted. Encrof of the } \\
\text { Estimate }\end{array}$ \\
\hline 1 & $700^{\circ}$ & 489 & 481 & 3412 \\
\hline
\end{tabular}

a. Predictors: (Constant), Kualitas Pelayanan, Persepsi Konsumen

b. Dependent Variabel: Kepuasan Konsumen Sumber: hasil pengolahan data dengan SPSS versi 21

Berdasarkan tabel 8 diperoleh nilai $r=$ 0,700 , yang artinya terdapat hubungan yang kuat dan positif antara kualitas pelayanan dan persepsi konsumen dengan kepuasan konsumen pada Eka Prima Motor Pematangsiantar. Kemudian diperoleh nilai koefisien determinasi ( $R$ Square $)=0,489$, artinya tinggi rendahnya kepuasan konsumen pada Eka Prima Motor Pematangsiantar sebesar $48,9 \%$ dapat dijelaskan oleh kualitas 
pelayanan dan persepsi konsumen, sedangkan sisanya sebesar $51,1 \%$ dipengaruhi oleh faktor lain seperti citra merek, kualitas produk, harga dan sebagainya yang tidak dibahas dalam penelitian ini.

\section{b) Hubungan antara Kualitas Pelayanan dengan Kepuasan Konsumen}

Hasil koefisien korelasi dan koefisien determinasi dapat dilihat pada tabel berikut:

Tabel 9

Hasil Korelasi dan Koefisen Determinasi Model Summary

\begin{tabular}{|l|r|r|r|r|}
\hline Nodel & $R$ & $R$ Square & $\begin{array}{c}\text { Adjusted } R \\
\text { Square }\end{array}$ & $\begin{array}{c}\text { Std. Emor of the } \\
\text { Estimate }\end{array}$ \\
\hline 1 &, $651^{3}$ &, 424 & 410 & 3610 \\
\hline
\end{tabular}

a. Predictors: (Constant), Kualitas Pelayanan b. Dependent Variabel: Kepuasan Konsumen Sumber: hasil pengolahan data dengan SPSS versi 21

Berdasarkan tabel 9 diperoleh nilai $r=$ 0,651 , yang artinya terdapat hubungan yang kuat dan positif antara kualitas pelayanan dengan kepuasan konsumen pada Eka Prima Motor Pematangsiantar. Kemudian diperoleh nilai koefisien determinasi (R Square) $=0,424$ artinya tinggi rendahnya kepuasan konsumen pada Eka Prima Motor Pematangsiantar sebesar $42,4 \%$ dapat dijelaskan oleh kualitas pelayanan, sedangkan sisanya sebesar $57,6 \%$ dipengaruhi oleh faktor lain seperti citra merek, kualitas produk, harga dan sebagainya yang tidak dibahas dalam penelitian ini.

\section{c) Hubungan antara Persepsi Konsumen dengan Kepuasan Konsumen}

Hasil koefisien korelasi dan koefisien determinasi dapat dilihat pada tabel berikut:

Tabel 10

Hasil Korelasi dan Koefisien Determinasi Model Summary ${ }^{b}$

\begin{tabular}{|l|r|r|r|r|}
\hline Vodel & $R$ & $R$ Square & $\begin{array}{l}\text { Aojusted } R \\
\text { Square }\end{array}$ & \multicolumn{1}{c|}{$\begin{array}{c}\text { Sid. Error of the } \\
\text { Estimate }\end{array}$} \\
\hline 1 &, $623^{\circ}$ &, 388 & 383 & 3722 \\
\hline
\end{tabular}

a. Predictors: (Constant), Persepsi Konsumen b. Dependent Variabel: Kepuasan Konsumen Sumber: hasil pengolahan data dengan SPSS versi 21

Berdasarkan tabel 10 diperoleh nilai $r=$ 0,623 , yang artinya terdapat hubungan yang kuat dan positif antara persepsi konsumen dengan kepuasan konsumen pada Eka Prima Motor Pematangsiantar. Kemudian diperoleh nilai koefisien determinasi ( $R$ Square $)=0,388$, artinya tinggi rendahnya kepuasan konsumen pada Eka Prima Motor Pematangsiantar sebesar $38,8 \%$ dapat dijelaskan oleh kualitas pelayanan, sedangkan sisanya sebesar $61,2 \%$ dipengaruhi oleh faktor lain seperti citra merek, kualitas produk, harga dan sebagainya yang tidak dibahas dalam penelitian ini.

\section{d) Hubungan antara Kepuasan Konsumen dengan Loyalitas Konsumen}

Hasil koefisien korelasi dan koefisien determinasi dapat dilihat pada tabel berikut:

Tabel 11

Hasil Korelasi dan Koefisien Determinasi

\begin{tabular}{|c|c|c|c|c|}
\hline Model & $R$ & R Square & $\begin{array}{l}\text { Adjusted } R \\
\text { Square }\end{array}$ & $\begin{array}{l}\text { Sro. Enor of the } \\
\text { Estimate }\end{array}$ \\
\hline 1 & $.687^{3}$ & 472 & ÂR & $3 \hat{2} 6.3$ \\
\hline
\end{tabular}

a. Predictors: (Constant), Kepuasan Konsumen b. Dependent Variabel: Loyalitas Konsumen Sumber: hasil pengolahan data dengan SPSS versi 21

Berdasarkan tabel 11 diperoleh nilai $r=$ 0,687 , yang artinya terdapat hubungan yang kuat dan positif antara kualitas pelayanan dengan kepuasan konsumen pada Eka Prima Motor Pematangsiantar. Kemudian diperoleh nilai koefisien determinasi ( $R$ Square) $=0,472$, artinya tinggi rendahnya kepuasan konsumen pada Eka Prima Motor Pematangsiantar sebesar $47,2 \%$ dapat dijelaskan oleh kualitas pelayanan, sedangkan sisanya sebesar $52,8 \%$ dipengaruhi oleh faktor lain seperti citra merek, kualitas produk, harga dan sebagainya yang tidak dibahas dalam penelitian ini.

3) Uji Hipotesis

a) Hipotesis 1

Pengaruh Kualitas Pelayanan dan Persepsi Konsumen terhadap Kepuasan Konsumen secara Simultan

Pengujian ini dilakukan secara simultan yaitu untuk menentukan diterima atau ditolaknya hipotesis, pengujian hipotesis dengan kriteria jika Fhitung > Ftabel atau signifikansi $\leq 0,05$ maka HO ditolak. Untuk menguji kebenarannya maka dilakukan pengujian hipotesis dengan menggunakan program aplikasi SPSS versi 21.

Tabel 12

Perkiraan Nilai $F_{\text {hitung }}$

ANOVA $^{a}$

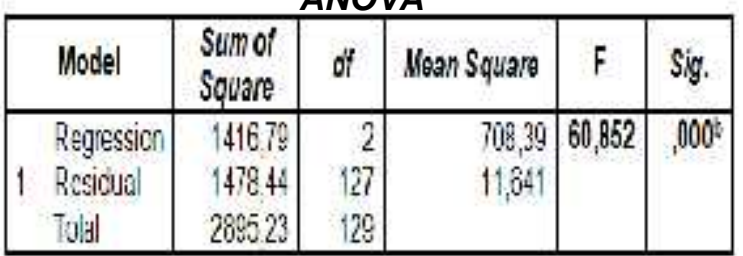

a. Dependent Variabel:Kepuasan Konsumen

b. Predictors: (Constant), Kualitas Pelayanan, Persepsi Konsumen

Sumber: hasil pengolahan data dengan SPSS versi 21

Berdasarkan tabel 12 di atas, diperoleh nilai $F_{\text {hitung }}$ sebesar $60,862>F_{\text {tabel }}$ dengan $(0,05$ ; 2 VS 127) dengan df = n-k-1 $(130-2-1=127)$ sebesar 3,07, atau dengan signifikansi $0,000<$ 
a 0,05 maka $\mathrm{H}_{0}$ ditolak, artinya kualitas pelayanan dan persepsi konsumen berpengaruh positif dan signifikan terhadap kepuasan konsumen pada Eka Prima Motor Pematangsiantar.

\section{b) Hipotesis 2}

\section{Pengaruh \\ Konsumen terhadap Kepuasan}

\section{Konsumen secara Parsial}

Pengujian ini dilakukan secara parsial yaitu untuk menentukan diterima atau ditolaknya hipotesis, pengujian hipotesis dengan kriteria jika thitung $>$ ttabel atau signifikansi $\leq \alpha \quad 0,05$ maka H0 ditolak. Untuk menguji kebenarannya maka dilakukan pengujian hipotesis dengan menggunakan program aplikasi SPSS versi 21. Berikut ditampilkan tabel mengenai perkiraan nilai thitung untuk $X 1$ (kualitas pelayanan) dan variabel X2 (persepsi konsumen) terhadap Z (kepuasan konsumen).

Tabel 13

Perkiraan Nilai thitung Coefficients $^{2}$

\begin{tabular}{|c|c|c|c|}
\hline & Model & $t$ & Sig. \\
\hline & Constard & 2.445 & .016 \\
\hline 1 & Kualings Pelazanan & 5,033 & .000 \\
\hline & Persersi Konsumen & 4,035 &, 000 \\
\hline
\end{tabular}

a. Dependent Variable: Kepuasan Konsumen Sumber: hasil pengolahan data dengan SPSS versi 21 (2017)

Berdasarkan tabel 13 di atas, diperoleh nilai $t_{\text {hitung }}$ pada variabel kualitas pelayanan sebesar 5,033 $>t_{\text {tabel }}$ dengan $d f=n-k-1,(130-2$ $1=127)$ sebesar 1,97882 atau taraf signifikansi $0,000<0,05$, maka $\mathrm{H}_{0}$ ditolak, artinya kualitas pelayanan berpengaruh positif dan signifikan terhadap kepuasan konsumen pada Eka Prima Motor Pematangsiantar.

Kemudian diperoleh nilai $t_{\text {hitung }}$ pada variabel persepsi konsumen sebesar 4,035 > $t_{\text {tabel }}$ dengan $\mathrm{df}=\mathrm{n}-\mathrm{k}-1 \quad(130-2-1=127)$ sebesar 1,97882 atau taraf signifikansi $0,000<\alpha 0,05$, maka $\mathrm{H}_{0}$ ditolak, artinya persepsi konsumen berpengaruh positif dan signifikan terhadap kepuasan konsumen pada Eka Prima Motor Pematangsiantar.

\section{c) Hipotesis 3}

Pengaruh Kepuasan Konsumen terhadap Loyalitas Konsumen

Pengujian ini dilakukan secara parsial yaitu dilakukan untuk menentukan diterima atau ditolaknya hipotesis, pengujian hipotesis dengan kriteria jika $t_{\text {hitung }}>t_{\text {tabel }}$ atau signifikansi $\leq \alpha \quad 0,05$ maka $H_{0}$ ditolak. Untuk menguji kebenarannya maka dilakukan pengujian hipotesis dengan menggunakan program aplikasi SPSS versi 21. Berikut ditampilkan tabel mengenai perkiraan nilai thitung untuk variabel kepuasan konsumen terhadap loyalitas konsumen.

Tabel 14

Perkiraan Nilai thitung Coefficients

\begin{tabular}{|ll|c|c|}
\hline \multicolumn{4}{|c|}{ Coefficients } \\
\hline \multirow{2}{|c|}{ Model } & $t$ & Sig. \\
\hline Constan') & 4,598 &, 000 \\
Kepuasan Konsumen & 10,696 &, 000 \\
\hline
\end{tabular}

a. Dependent Variable: Loyalitas Konsumen Sumber: hasil pengolahan data dengan SPSS versi 21 (2017)

Berdasarkan tabel 14 di atas, diperoleh nilai thitung pada variabel kepuasan konsumen sebesar 10,696 > ttabel dengan df $=\mathrm{n}-\mathrm{k}-1$ (130$1-1=128)$ sebesar 1,97867 atau taraf signifikansi $0,000<\alpha \quad 0,05$, maka HO ditolak, artinya kepuasan konsumen berpengaruh positif dan signifikan terhadap loyalitas konsumen pada Eka Prima Motor Pematangsiantar.

\section{Evaluasi}

a. Kualitas Pelayanan pada Eka Prima Motor

\section{Pematangsiantar}

Kualitas pelayanan yang ada pada Eka Prima Motor Pematangsiantar dapat dikatakan baik, hal ini dapat dilihat dari hasil kuesioner yang dibagikan kepada responden yang secara keseluruhan diperoleh nilai rata-rata 3,74 dengan kriteria jawaban baik. Namun ada beberapa indikator kualitas pelayanan pada Eka Prima Motor Pematangsiantar yang menjadi perhatian seperti pada dimensi bukti langsung (tangible) dengan indikator kelengkapan seragam karyawan diperoleh nilai rata-rata 2,57 dengan kriteria jawaban tidak baik, cara memperbaikinya adalah sebaiknya pimpinan Eka Prima Motor Pematangsiantar memberikan seragam yang lengkap bagi karyawan baik kasir maupun mekanik. Pada dimensi kehandalan (reliability) dengan indikator kenyamanan yang dirasakan diperoleh nilai rata-rata 3,65 dengan kriteria jawaban baik, cara meningkatkannya adalah sebaiknya pihak Eka Prima Motor Pematangsiantar lebih meningkatkan kualitas jaringan wifi yang disediakan bagi konsumen yang sedang menunggu sehingga konsumen akan merasa lebih nyaman.

Pada dimensi jaminan (assurance) dengan indikator kesesuaian pekerjaan dengan prosedur pekerjaan diperoleh nilai rata-rata 3,60 dengan kriteria jawaban baik, cara meningkatkannya adalah sebaiknya pimpinan Eka Prima Motor Pematangsiantar memberikan pelatihan kepada karyawan agar menambah pengetahuan karyawan mengenai mesin mobil.

Pada dimensi empati (empathy) dengan indikator pertanggungjawaban informasi diperoleh nilai rata-rata 3,63 dengan kriteria jawaban baik, cara memperbaikinya adalah sebaiknya baik pimpinan maupun karyawan Eka Prima Motor Pematangsiantar memberikan 
informasi dengan jelas dan mampu mempertanggungjawabkan informasi yang disampaikan.

Kualitas pelayanan pada Eka Prima Motor Pematangsiantar dalam hal ini sudah dikategorikan baik. Walaupun sudah dikategorikan baik sebaiknya pimpinan berusaha untuk meningkatkan pelayanan yang diberikan dengan memberikan fasilitas ruang tunggu yang nyaman serta memberikan perhatian kepada konsumen.

\section{b. Persepsi Konsumen pada Eka Prima Motor Pematangsiantar}

Persepsi konsumen pada Eka Prima

Motor Pematangsiantar dapat dikatakan baik, hal ini dapat dilihat dari hasil kuesioner yang dibagikan kepada responden yang secara keseluruhan diperoleh nilai rata-rata 3,63 dengan kriteria jawaban setuju.

Namun ada beberapa aspek yang dinilai baik tetapi masih di bawah rata-rata, yaitu pada dimensi distorsi selektif dengan indikator keyakinan bahwa Eka Prima Motor Pematangsiantar adalah bengkel yang terbaik diperoleh nilai rata-rata 2,96 dengan kriteria jawaban cukup setuju, cara meningkatkannya sebaiknya Eka Prima Motor Pematangsiantar memberikan pelayanan yang terbaik agar konsumen meyakini bahwa Eka Prima Motor Pematangsiantar adalah bengkel yang terbaik.

Pada dimensi ingatan selektif dengan indikator memilih Eka Prima Motor Pematangsiantar tanpa memperhatikan bengkel lain diperoleh nilai rata-rata 2,92 dengan kriteria jawaban cukup setuju, cara meningkatkannya sebaiknya Eka Prima Motor Pematangsiantar memberikan sesuatu yang unik yang tidak dimiliki oleh pesaing sehingga konsumen selalu mengingat Eka Prima Motor Pematangsiantar ketika ingin memperbaiki kendaraannya.

Persepsi konsumen pada Eka Prima Motor Pematangsiantardalam hal ini sudah dikategorikan baik. walaupun sudah dikategorikan baik, sebaiknya pihak Eka Prima Motor Pematangsiantar lebih meningkatkan mutu pelayanan dan memenuhi keinginan konsumen sehingga konsumen akan memberikan persepsi yang positif terhadap Eka Prima Motor Pematangsiantar.

\section{c. Kepuasan Konsumen pada Eka Prima Motor Pematangsiantar}

Tingkat kepuasan konsumen pada Eka Prima Motor Pematangsiantar sudah baik. Hal ini dapat dilihat dari jawaban responden dengan nilai rata-rata keseluruhan rata-rata sebesar 3,66 dengan kriteria jawaban puas.

Namun tentunya ada beberapa indikator yang perlu diperhatikan karena nilainya masih dibawah rata-rata, seperti pada dimensi harga produk dengan indikator harga yang ditawarkan diperoleh nilai rata-rata 3,12 dengan kriteria jawaban cukup puas, cara meningkatkannya adalah sebaiknya Eka Prima Motor Pematangsiantar memberikan harga yang mudah dijangkau oleh konsumen dan sesuai dengan kualitas dari produk serta jasanya. Kemudian pada indikator variasi harga produk diperoleh nilai rata-rata 3,23 dengan kriteria jawaban cukup puas, cara memperbaikinya adalah sebaiknya Eka Prima Motor Pematangsiantar memberikan variasi harga yang tidak terlalu tinggi.

Pada dimensi dukungan konsumen dengan indikator proses pelayanan yang memberikan kemudahan diperoleh nilai ratarata 3,65 dengan kriteria jawaban puas, cara meningkatkannya adalah sebaiknya Eka Prima Motor Pematangsiantar lebih memberikan kemudahan bagi konsumen yang ingin menservis atau memperbaiki kendaraannya.

Kepuasan konsumen pada Eka Prima Motor Pematangsiantar dalam hal ini sudah dikategorikan baik. Meskipun sudah dikategorikan baik, sebaiknya pimpinan tetap memberikan pelayanan dan perhatian yang baik, sehingga konsumen akan merasa semakin puas.

\section{d. Loyalitas Konsumen pada Eka Prima Motor Pematangsiantar}

Loyalitas konsumen pada Eka Prima Motor Pematangsiantar dapat dikategorikan baik. hal ini dapat dilihat dari hasil jawaban kuesioner yang dibagikan kepada responden yang secara keseluruhan diperoleh nilai ratarata 3,82 dengan kriteria jawaban tinggi.

Namun ada beberapa indikator loyalitas konsumen yang perlu diperhatikan karena nilainya masih dibawah rata-rata, seperti pada dimensi melakukan pembelian secara terus menerus dengan indikator frekuensi kunjungan diperoleh nilai rata-rata 3,70 dengan kriteria jawaban tinggi, cara meningkatkannya adalah sebaiknya Eka Prima Motor Pematangsiantar lebih meningkatkan pelayanan yang diberikan sehingga konsumen tidak bosan untuk datang kembali ke Eka Prima Motor Pematangsiantar.

Pada dimensi membeli antar lini produk dan jasa dengan indikator menggunakan produk lain yang ditawarkan diperoleh nilai ratarata 2,98 dengan kriteria jawaban sedang, cara memperbaikinya adalah sebaiknya Eka Prima Motor Pematangsiantar menawarkan produk lain yang dibutuhkan konsumen dengan kualitas yang lebih baik dari pesaing serta melakukan promosi terhadap produk dan jasa lain yang ditawarkan. Pada indikator menawarkan produk ke pihak lain diperoleh nilai rata-rata 3,61 dengan kriteria jawaban tinggi, cara meningkatkannya adalah sebaiknya Eka Prima Motor Pematangsiantar menawarkan produk dan jasa bengkel yang bermutu tinggi sehingga konsumen bersedia menawarkannya ke pihak lain. 
Loyalitas konsumen pada Eka Prima Motor Pematangsiantar dalam hal ini sudah dikategorikan baik. walaupun sudah dikategorikan baik, sebaiknya pimpinan berusaha menjalin hubungan yang dekat dengan konsumen dan memberikan perhatian agar konsumen menjadi loyal.

\section{KESIMPULAN DAN SARAN}

\section{Kesimpulan}

a. Hasil analisis deskriptif kualitatif kualitas pelayanan pada Eka Prima Motor Pematangsiantar berada pada rata-rata keseluruhan sebesar 3,74 dengan kriteria jawaban baik. Nilai rata-rata tertinggi sebesar 4,05 pada dimensi jaminan (assurance) dengan indikator kesopanan karyawan dalam melayani konsumen. Sedangkan nilai rata-rata terendah sebesar 2,57 pada dimensi bukti langsung (tangible) dengan indikator kelengkapan seragam karyawan.

b. Hasil analisis deskriptif kualitatif persepsi konsumen pada Eka Prima Motor Pematangsiantar berada pada rata-rata keseluruhan sebesar 3,63 dengan kriteria jawaban setuju. Nilai rata-rata tertinggi sebesar 4,03 pada dimensi perhatian selektif dengan indikator memperhatikan informasi yang disampaikan karyawan. Sedangkan nilai rata-rata terendah sebesar 2,92 pada dimensi ingatan selektif dengan indikator memilih Eka Prima Motor Pematangsiantar tanpa memperhatikan bengkel lain.

c. Hasil analisis deskriptif kualitatif kepuasan konsumen pada Eka Prima Motor Pematangsiantar berada pada rata-rata keseluruhan sebesar 3,66 dengan kriteria jawaban puas. Nilai rata-rata tertinggi sebesar 3,90 pada dimensi kualitas produk dan jasa dengan indikator hasil servis atau perbaikan mobil. Sedangkan nilai rata-rata terendah sebesar 3,12 pada dimensi harga produk dengan indikator harga yang ditawarkan.

d. Hasil analisis deskriptif kualitatif loyalitas konsumen pada Eka Prima Motor Pematangsiantar berada pada rata-rata keseluruhan sebesar 3,82 dengan kriteria jawaban tinggi. Nilai rata-rata tertinggi sebesar 4,08 pada dimensi mereferensikan kepada orang lain dengan indikator mengajak teman untuk datang ke Eka Prima Motor Pematangsiantar. Sedangkan nilai rata-rata terendah sebesar 2,98 pada dimensi membeli antar lini produk dan jasa dengan indikator menggunakan produk lain yang ditawarkan.

e. Kualitas pelayanan dan persepsi konsumen memiliki pengaruh yang positif terhadap kepuasan konsumen pada Eka Prima Motor Pematangsiantar yang dibuktikan dengan hasil regresi $\quad \hat{Y}_{Z}=8,042+0,345 X_{1}+$
0,506 $\mathrm{X}_{2}$. Kepuasan konsumen memiliki pengaruh yang positif terhadap loyalitas konsumen pada Eka Prima Motor Pematangsiantar yang dibuktikan dengan hasil regresi $\hat{Y}=13,826+0,728 Z$.

f. Kualitas pelayanan dan persepsi konsumen memiliki hubungan yang kuat dan positif dengan kepuasan konsumen pada Eka Prima Motor Pematangsiantar yang dibuktikan dengan nilai $r$ sebesar 0,700 dan nilai koefisien determinasi ( $\mathrm{R}$ Square) sebesar 0,489 (48,9\%). Kemudian kepuasan konsumen memiliki hubungan yang kuat dan positif dengan loyalitas konsumen pada Eka Prima Motor Pematangsiantar yang dibuktikan dengan nilai $r$ sebesar 0,687 dan nilai koefisien determinasi ( $R$ Square) sebesar 0,472 (47,2\%).

g. Kualitas pelayanan dan persepsi konsumen berpengaruh positif dan signifikan terhadap kepuasan konsumen pada Eka Prima Motor Pematangsiantar secara simultan dibuktikan dengan hasil uji hipotesis 1 diperoleh nilai $F_{\text {hitung }}$ sebesar $60,852>F_{\text {tabel }}$ dengan $(0,05$; 2 VS 127) sebesar 3,07 atau taraf signifikansi sebesar $0,000<\alpha 0,05$.

h. Kualitas pelayanan berpengaruh positif dan signifikan terhadap kepuasan konsumen pada Eka Prima Motor Pematangsiantar dibuktikan denganhasil uji hipotesis 2 diperoleh nilai $t_{\text {hitung }}$ pada variabel $X_{1}$ (kualitas pelayanan) sebesar 5,033 $>t_{\text {tabel }}$ dengan df $=\mathrm{n}-\mathrm{k}-1 \quad(130-2-1=127)$ sebesar 1,97882 atau taraf signifikansi $0,000<\alpha$ 0,05 . Kemudian persepsi konsumen berpengaruh positif dan signifikan terhadap kepuasan konsumen pada Eka Prima Motor Pematangsiantar secara parsial dibuktikan dengan hasil uji hipotesis pada variabel $X_{2}$ (persepsi konsumen) diperoleh nilai $t_{\text {hitung }}$ sebesar 4,035 $>t_{\text {tabel }}$ dengan $d f=n-k-1(130$ $2-1=127$ ) sebesar 1,97882 atau taraf signifikansi $0,000<\alpha 0,05$.

i. Kepuasan konsumen berpengaruh positif dan signifikan terhadap loyalitas konsumen pada Eka Prima Motor Pematangsiantardibuktikan dengan hasil uji hipotesis 3 diperoleh nilai $t_{\text {hitung }}$ pada variabel Z (kepuasan konsumen) sebesar 10,696 > $t_{\text {tabel }}$ dengan df $=n-k-1 \quad(130-1-1=128)$ sebesar 1,97867 atau taraf signifikansi 0,000 $<\alpha 0,05$.

\section{Saran}

a. Kualitas pelayanan pada Eka Prima Motor Pematangsiantar masih perlu ditingkatkan karena masih ada indikator yang belum optimal. Untuk itu sebaiknya pimpinan Eka Prima Motor Pematangsiantar meningkatkan kualitas pelayanan dengan memberikan seragam yang lengkap kepada karyawan, memberi pelatihan kepada karyawan agar lebih tanggap ketika menangani keluhan 
konsumen, serta memberikan perhatian kepada konsumen sehingga konsumen akan merasa puas dengan pelayanan yang diterimanya.

b. Persepsi konsumen pada Eka Prima Motor Pematangsiantar masih perlu ditingkatkan, untuk itu sebaiknya Eka Prima Motor Pematangsiantar mampu memenuhi harapan konsumen dan memberikan informasi yang jelas kepada konsumen sehingga konsumen akan memberikan persepsi yang positif terhadap Eka Prima Motor Pematangsiantar.

c. Kepuasan konsumen pada Eka Prima Motor Pematangsiantar masih perlu ditingkatkan karena masih ada indikator yang belum optimal. Untuk meningkatkan kepuasan konsumen, maka sebaiknyaEka Prima Motor Pematangsiantar menawarkan harga yang mudah dijangkau konsumen, memberikan potongan harga, dan mengoptimalkan penanganan keluhan konsumen.

d. Loyalitas konsumen pada Eka Prima Motor Pematangsiantar masih perlu ditingkatkan karena masih ada indikator yang belum optimal. Untuk mengoptimalkan loyalitas konsumen, maka sebaiknya Eka Prima Motor Pematangsiantar menawarkan produk dengan mutu tinggi dan berkualitas. Pimpinan Eka Prima Motor Pematangsiantar juga sebaiknya lebih menjalin hubungan yang lebih baik kepada konsumen sehingga konsumen merasa dihargai dan konsumen akan loyal dengan Eka Prima Motor Pematangsiantar.

\section{DAFTAR PUSTAKA}

Griffin, Jill. 2003. Customer Loyalty : Menumbuhkan dan Mempertahankan Kesetiaan Pelanggan Edisi Revisi dan Terbaru, Terj. Dwi Kartini Yahya. Jakarta: Erlangga

Irawan, Hadi. 2003. Kepuasan Pelayanan Jasa. Jakarta: Erlangga

Juwandi, Hendy Irawan. 2004. Kepuasan Pelayanan Jasa. Jakarta: Erlangga

Kotler, Philip. 2007. Manajemen Pemasaran. Edisi 12, Jilid 1. Jakarta: PT. Indeks

Kotler, Philip dan Gary Amstrong. 2004. DasarDasar Pemasaran, Edisi Kesembilan, Jilid 1. Jakarta: Indeks
Kotler, Philip dan Kevin Lane Keller. 2007. Manajemen Pemasaran. Edisi Kedua Belas, Jilid 1. Jakarta: Indeks

Kotler, Philip dan Kevin Lane Keller. 2009. Manajemen Pemasaran, Edisi Ketiga Belas, Jilid 1. Jakarta: Erlangga

Lovelock, Chistoper. H dan Laurence S. Wright. 2005. Manajemen Pemasaran Jasa. Jakarta: PT Indeks

Lupiyoadi, Rambat dan A. Hamdani. 2006. Manajemen Pemasaran Jasa. Edisi 2. Jakarta: Salemba Empat

2008. Manajemen Pemasaran Jasa. Jakarta: Salemba Empat

Nasution, M. Nur. 2005. Reformasi Birokrasi: Peningkatan Mutu Pelayanan Publik. Semarang: Universitas Diponegoro

Schiffman, Leon dan Leslie Lazar Kanuk. 2007. Perilaku Konsumen, Edisi Ketujuh. Jakarta: Indeks

Setiadi, Nugroho J. 2008. Perilaku Konsumen: Konsep dan Implikasi untuk Strategi dan Penelitian Pemasaran. Jakarta: Kencana

Sunarto. 2003. Perilaku Konsumen. Yogyakarta: Amus Yogyakarta dan CV Ngeksigondo Utama

Tjiptono, Fandy. 2000. Prinsip dan Dinamika Pemasaran, Edisi Pertama. Yogyakarta: J. J. Learning

Tjiptono, Fandy. 2005. Service Quality \& Satisfaction, Yogyakarta: Andi

........ 2007. Strategi Pemasaran, Edisi Kedua. Yogyakarta: Andi

Tjiptono, Fandy dan Gregorius Chandra. 2011. Service, Quality \& Satisfaction. Yogyakarta: Andi

Tjiptono. Fandy dan Walkin. 2007. Total Equity Management. Yogyakarta: Andi

Wisnalmawati. 2005. Pengaruh Persepsi Dimensi Kualitas Layanan Terhadap Niat Pembelian Ulang Jurnal Ekonomi \& Bisnis. Jilid 10. Yogyakarta: UPN "Veteran" 